Pak. j. sci. ind. res. Ser. A: phys. sci. 2020 63A(1) 18-29

\title{
Biosorption of $\mathrm{Pb}(\mathrm{II})$ and $\mathrm{Cd}(\mathrm{II})$ Ions from Aqueous Solution by Chemically Modified Syzygium cumini Leaves and its Equilibrium, Kinetic and Thermodynamic Studies
}

\author{
Syed Muhammad Salmana, Sardar Muhammad a , Durr e Shahwarb, \\ Mahmood Iqbal ${ }^{\mathfrak{*}}$, Muhammad Aijaz ${ }^{\mathrm{e}}$, Muhammad Siddiquec, Asad Alia, \\ Saleem Nawaz ${ }^{a}$ and Abdul Waheed Kamran ${ }^{d}$ \\ ${ }^{a}$ Department of Chemistry, Islamia College University, Peshawar-25000, Khyber Pakhtunkhwa, Pakistan \\ ${ }^{b}$ Department of Zoology, Islamia College University, Peshawar-25000, Khyber Pakhtunkhwa, Pakistan \\ 'PCSIR Laboratories Complex, Jamrud Road, Peshawar-25120, Khyber Pakhtunkhwa, Pakistan \\ ${ }^{d}$ Department of Chemistry, University of Malakand, Khyber Pakhtunkhwa, Pakistan \\ ePCSIR Laboratories Complex, Shahrah-e-Dr. Salimuzzamn Siddiqui, \\ Off University Road, Karachi-75280, Pakistan
}

(received December 19, 2018; revised May 13, 2019; accepted May 20, 2019)

\begin{abstract}
The removal of $\mathrm{Pb}$ (II) and $\mathrm{Cd}$ (II) ions from aqueous solution by a novel low-cost biosorbent; chemically modified Syzygium cumini leaves (CMSCL) was studied. The effects of biomass dosage, $\mathrm{pH}$, concentration, temperature and contact time were investigated. Characterization of CMSCL was carried out by FT-IR spectroscopy, pore size, and surface area analyzer. The maximum biosorption capability of CMSCL for $\mathrm{Pb}$ (II) and Cd (II) ions was 104 and $50 \mathrm{mg} / \mathrm{g}$ at optimum conditions of $\mathrm{pH} 6$ and 7, biomass dosage of $5 \mathrm{~g} / \mathrm{L}$, contact time of 120 and $90 \mathrm{~min}$ and temperature of 50 and $40{ }^{\circ} \mathrm{C}$, respectively. The experimental data was analyzed using pseudo-first order and pseudo-second order kinetics models. The biosorption of $\mathrm{Pb}$ (II) and Cd (II) followed pseudo-second order model. Langmuir, Freundlich and Temkin adsorption isotherm models were applied to explain the removal of heavy metal ions by CMSCL biosorbent. Langmuir isotherm model fitted better than other isotherm models. Thermodynamics parameters such as $\Delta \mathrm{H}^{\circ}, \Delta \mathrm{G}^{\circ}$ and $\Delta \mathrm{S}^{\circ}$ showed that the biosorption of $\mathrm{Pb}$ (II) and Cd (II) ions onto CMSCL was spontaneous, exothermic and feasible under examined conditions. The occurrence of various functional groups and change in the absorption frequency after metal uptake indicates that complexation was the main mechanism involved in the process of biosorption. Based on the present investigation, it was proved that CMSCL is an effective, alternative and economical biosorbent for the removal of $\mathrm{Pb}$ (II) and $\mathrm{Cd}$ (II) ions.
\end{abstract}

Keywords: Syzygium cumini, biosorption, lead, cadmium

\section{Introduction}

The occurrence of heavy metals like $\mathrm{Pb}, \mathrm{Cd}, \mathrm{Cr}$, etc. has caused serious environmental problem for the aquatic system. These contaminants are not decomposed by living organisms and can accumulate in their body tissues. The occurrence of heavy metals in the aqueous system and their influences on the living organism is a problem of concern since a long time ago. $\mathrm{Pb}$ (II) and Cd (II) are very toxic metals of high atomic masses (Reddy et al., 2010b). Industries of ceramic glass, matches, pigments, mining, storage batteries, smelting, metal plating, ammunition, oil refining, and painting are the main sources which discharge $\mathrm{Pb}$ (II) and $\mathrm{Cd}$ (II) ions into the aquatic system (Schneegurt et al., 2001). The maximum permissible limit of $\mathrm{Pb}$ (II) ions

*Author for correspondence;

E-mail: mahmood2162002@gmail.com in drinking water is $0.05 \mathrm{ppm}$ given by the US environmental protection agency (USEPA) and WHO (Agency, 2002; Organization, 1996). Higher concentration of $\mathrm{Pb}$ (II) ions than the permissible limit causes a serious threat to brain, kidney, reproductive system, liver, and nervous system (Soliman et al., 2016). Heavy metals are non-biodegradable and their removal from the aquatic medium is necessary before they contaminate the drinking water and accumulate in the body.

The conventional methods used to remove $\mathrm{Pb}$ (II) and Cd (II) ions include precipitation, ion exchange, membrane filtration, oxidation and reduction and adsorption by activated carbon (Wang et al., 2003). However, these methods are expensive and produce chemical sludge which creates serious problem when disposed of and also fail to remove metal ions below $100 \mathrm{ppm}$. Therefore, nowadays it is a challenge to 
explore more efficient and economical methods to treat the heavy metals ions.

The biosorption method is a very simple and economical process. The chemically modified Syzygium cumini leaves (CMSCL) bind metals of high atomic masses on their surface if present in aqueous medium and waste water (Yang and Volesky, 1999). The important application of CMSCL as agriculture biomass, where toxic metals of high atomic masses can effectively be removed. The plant based biosorbent is cheap, easily regenerated and can be reused and metals of high atomic masses can be easily eliminated. Previously many plant leaves have been successfully utilized to eliminate heavy metal ions, including; Diceriocaryum eriocarpum leaves, (Edokpayi et al., 2015) and Melia azedarach leaves (Khokhar and Siddique, 2015) and Phytolacca americana leaves (Wang et al., 2018) and Salvia moorcroftiana leaves (Salman et al., 2019) and Leucaena leucocephala residues (Cima-Mukul et al., 2019) and mango leaves (Adelaja et al., 2019) and Aloe barbadensis leaves (Gupta et al., 2019) and peel of Artocarpus nobilis (Priyantha and Kotabewatta, 2019).

Tree leaves are efficient adsorbents which successfully remove toxic metals of high atomic masses from aqueous solution in which functional groups hydroxyl, carbonyl, amino and ether group may be present which are important binding sites for heavy metals. Syzygium cumini is well known tropical tree native from Indian subcontinent, but widely cultivated in many countries in south America, Africa and Asia (Chagas et al., 2015). The $\mathrm{Pb}$ (II) and $\mathrm{Cd}$ (II) ions can be removed by using leaves of Syzygium cumini as adsorbent. Chemical modification of tree leaves enhances their adsorption capacity of heavy metal ions (Ngah and Hanafiah, 2008) therefore, selected leaves were chemically modified.

The aim of the present study was pretreatment and modification of biosorbent to improve its sorption capacity. The prospective application of biosorbent and biosorption of $\mathrm{Pb}$ (II) and $\mathrm{Cd}$ (II) ions in the aquatic system was discussed. The effects of different parameters such as $\mathrm{pH}$, initial metals ions concentration, biomass dosage, contact time and temperature were studied. Moreover, the kinetic, thermodynamic and isothermal studies were also conducted.

\section{Materials and Methods}

Preparation and chemical modification of Syzygium cumini leaves. The leaves of Syzygium cumini were collected, extensively washed and shadow dried. The dried leaves were kept in an electric oven for $24 \mathrm{~h}$ at $40{ }^{\circ} \mathrm{C}$ to remove the vapours. The brittle dried leaves were ground into powder by the electrical grinder. 45 mish size particles were selected and soaked in $0.1 \mathrm{M}$ nitric acid which was kept for $24 \mathrm{~h}$. The solution having nitric acid treated Syzygium cumini leaves were filtered and washed with double distilled water to remove excess $\mathrm{HNO}_{3}$. The nitric acid treated Syzygium cumini leaves was first dried in the open air and after in oven at 100 ${ }^{\circ} \mathrm{C} .50 \mathrm{~g}$ acid treated Syzygium cumini leaves treated with $0.1 \mathrm{M} \mathrm{CaCl}_{2}$ solution for $24 \mathrm{~h}$. The excess $\mathrm{CaCl}_{2}$ was removed from the chemically modified Syzygium cumini leaves (CMSCL) by filtration and washing with double distilled water. The CMSCL was dried at room temperature and put in the vacuum oven at $105^{\circ} \mathrm{C}$ for complete removal of moisture. The CMSCL was treated with acid to remove the impurities and metals ions present on its surface. Moreover, biosorbent was treated with calcium chloride to load calcium metal on biosorbent surface which work as ion exchanger for the removal toxic metals.

Chemicals, solutions and instruments. All chemicals and reagents analytical standard were purchased from Sigma Aldrich, Merck and Fisher companies. The solutions of $\mathrm{Pb}$ (II) and $\mathrm{Cd}$ (II) ions were prepared by dissolving $1.0 \mathrm{~g} / \mathrm{L} \mathrm{Pb}\left(\mathrm{NO}_{3}\right)_{2}$ and $\mathrm{CdCl}_{2}$ in doubled distilled water.

Atomic absorption spectrophotometer of Z-2000 series was used for the determination of the metal concentrations. Mettler balance was used for weighing various chemicals and chemically modified Syzygium cumini leaves (CMSCL) powder. Fourier transformed infrared spectrophotometer (Prestige-21) from Shimadzu Japan was used for the functional group's identification. NOVA, 2200e, USA was used for surface morphology, surface area and pore size analyses. To determine the $\mathrm{pH}$ of the solution a digital Mettler Delta 320 hydrogen ion concentration meter was used. The variable speed shaker from (40-400 rpm) having a temperature controller up to $70^{\circ} \mathrm{C}$ was used.

Characterization of chemically modified Syzygium cumini leaves (CMSCL). The removal of heavy metal ions is linked with the nature of biosorbent. The functional groups present in the CMSCL were identified by using FTIR spectrophotometer. This technique also helps to understand the mechanism of biosorption. 0.05 $\mathrm{g}$ sample of biomass was pressed from 3 to 5 barometric 
pressure. Frequency ranging from $400-4000 / \mathrm{cm}$ was used for spectral analysis. Pores size and surface area are the important parameters of the biosorbent. Biosorption capacity increases by raising the surface area of the biosorbent. The good biosorbent is that which has a greater number of small pores size surface area, pore volume and pore diameter were investigated by using the analyzer (NOVAS200e, Quantachrome, USA).

Batch biosorption experiment. Batch biosorption was performed to determine the removal of $\mathrm{Pb}$ (II) and $\mathrm{Cd}$ (II) ions in the aqueous system of $100 \mathrm{~mL}$ volume that was selected for all experiments. $5 \mathrm{~g}$ biosorbent was used to determine the biosorbent concentration effect. For biosorption experiments, the shaking speed was kept constant at $180 \mathrm{rpm}$. The $\mathrm{pH}$ was adjusted from 2.0 to 7.0 using $0.1 \mathrm{M}$ solution of $\mathrm{HCl}$ and $0.1 \mathrm{M}$ solution of $\mathrm{NaOH}$. Similarly, a solution concentration of $100 \mathrm{ppm}$ was used in the experiment. The metal adsorption capacity of CMSCL for $\mathrm{Pb}$ (II) and Cd (II) ions were determined by using the given formula:

$$
q e=V \times \frac{\left(C_{o}-C_{e}\right)}{m}
$$

where:

$\mathrm{q}_{\mathrm{e}}$ is the metal quantity adsorbed ( $\mathrm{mg} / \mathrm{g}$ ) for the (CMSCL), $\mathrm{C}_{\mathrm{o}}$ is the initial equilibrium concentration $(\mathrm{mg} / \mathrm{L})$ and $\mathrm{C}_{\mathrm{e}}$ is the final equilibrium concentration $(\mathrm{mg} / \mathrm{L})$ of the metal ions in the aqueous solution, $\mathrm{m}$ is mass in grams (g) of the CMSCL used in the process and V is the volume $\left(\mathrm{dm}^{3}\right)$ of the solution.

\section{Results and Discussion}

Biosorbent and its characterization. Surface area was analyzed by Barrett-Joyner-Halenda (BJH), pore volume and pore diameters were calculated by using BrunauerEmmett-Teller (BET) shown in Table 1. The results reveal that CMSCL has the greater surface area and very high porosity making it a good biosorbent.

FTIR analysis of biomass. FT-IR spectra of chemically modified Syzygium cumini leaves, $\mathrm{Pb}$ loaded CMSCL and Cd loaded CMSCL are shown in Fig. 1a-c, respectively. The FTIR spectra of $\mathrm{Pb}$ (II) and Cd (II) unloaded CMSCL showed the presence of various functional groups. The absorption at $2928 / \mathrm{cm}$ shows the stretching vibration of $\mathrm{C}-\mathrm{H}$ in $\mathrm{C}=\mathrm{C}-\mathrm{H}$ and $-\mathrm{CH}_{2}$ groups. The peak located at 1322/cm exhibits -NH functional group. The peak at $1159 / \mathrm{cm}$ represents the $\mathrm{CN}$ stretching. $\mathrm{CO}$ and $\mathrm{C}-\mathrm{OH}$ stretching vibration showed peaks in the $1080 / \mathrm{cm}$ and 1035/cm region respectively (Anayurt et al., 2009a).

Table 1. Surface area, pore volume and pore diameter of CMSCL biomass

\begin{tabular}{lllll}
\hline \hline Biosorbent & $\begin{array}{l}\text { BET } \\
\text { surface } \\
\text { area } \\
\mathrm{m}^{2} / \mathrm{g}\end{array}$ & $\begin{array}{l}\mathrm{BJH} \\
\text { surface } \\
\text { area } \\
\mathrm{m}^{2} / \mathrm{g}\end{array}$ & $\begin{array}{l}\text { Pore } \\
\text { volume } \\
\mathrm{cm}^{3} / \mathrm{g}\end{array}$ & $\begin{array}{l}\text { Pore } \\
\text { diameter } \\
\AA\end{array}$ \\
\hline $\mathrm{CMSCL}$ & 72.68 & 293.26 & 0.96 & 133.00 \\
\hline \hline
\end{tabular}
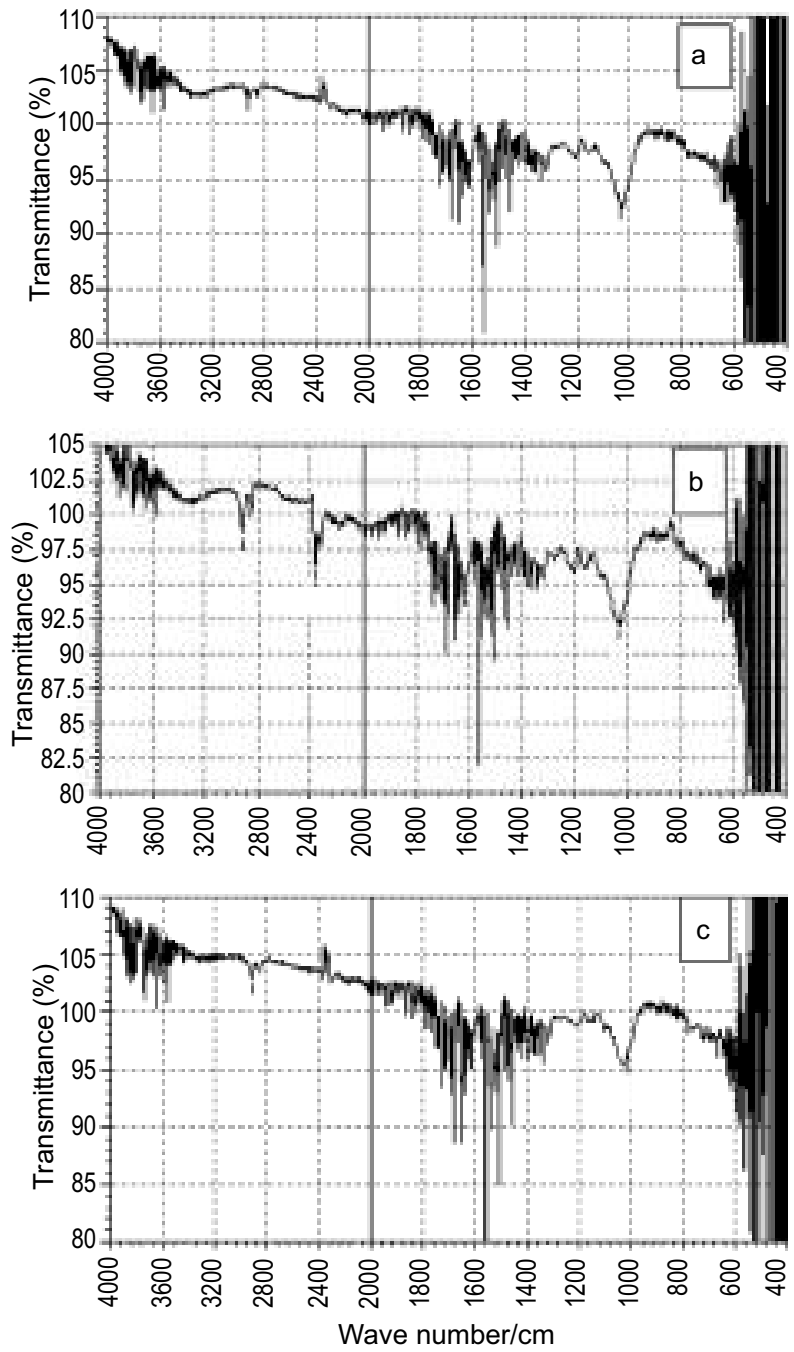

Fig. 1. FT-IR spectra of (a) the biosorbent of CMSCL (b) biomass treated with $\mathrm{Pb}$ (II) solution, (c) biomass treated with Cd (II) solution. 
The Pb (II) loaded FTIR spectra of CMSCL showed wavenumber shift of many functional groups. Meanwhile, the wave number of absorption peaks were moved from $2927 / \mathrm{cm}, 1153 / \mathrm{cm}$ and $1035 / \mathrm{cm}$ to $2918 / \mathrm{cm}$, $1153 / \mathrm{cm}$ and $1028 / \mathrm{cm}$, respectively. The FTIR data clearly indicates the involvement of $\mathrm{C}=\mathrm{O}, \mathrm{OH}$ and $\mathrm{CN}$ groups in $\mathrm{Pb}$ biosorption. FTIR spectra of $\mathrm{Cd}$ loaded CMSCL indicates the involvement of $\mathrm{C}=\mathrm{O}$ and $-\mathrm{OH}$ groups for Cd (II) biosorption, due to shifting of the absorption peaks from $2928 / \mathrm{cm}$ and $1036 / \mathrm{cm}$ to $2918 / \mathrm{cm}$ and 1019/cm, respectively (Yu et al., 2007).

Batch biosorption experimental works. pH effect. $\mathrm{pH}$ effect is the important parameter for the biosorption of $\mathrm{Pb}$ (II) and $\mathrm{Cd}$ (II) ions onto CMSCL. Biosorption was performed by changing $\mathrm{pH}$ values from 2-7 and the experimental data is shown in Fig. 2. The maximum elimination for $\mathrm{Pb}$ (II) and $\mathrm{Cd}$ (II) ions was achieved at $\mathrm{pH} 6.0$ and 7.0. respectively. It was noted that when the concentration of hydrogen ions increases the removal of metal ions also increases and maximum removal of $\mathrm{Pb}$ (II) and $\mathrm{Cd}$ (II) ions onto CMSCL biosorbent was obtained at $\mathrm{pH} 6.0$ and $\mathrm{pH} 7.0$, respectively. Figure 2 showed that at low $\mathrm{pH}$ the binding places become saturated with hydrogen ions and compete for the positive $\mathrm{Pb}$ (II) and $\mathrm{Cd}$ (II) ions to be adsorbed (Amegrissi et al., 2013). Beyond optimum pH, biosorption decreases and the biosorption sites at higher $\mathrm{pH}$ do not get activated. Ionic precipitation of metal hydroxides occurs at higher $\mathrm{pH}$ value given in Fig. 2.

Biosorbent dose effect. The biosorbent dose variation was studied for the removal of $\mathrm{Pb}$ (II) and $\mathrm{Cd}$ (II) ions. To study the influence of CMSCL, dose was changed from $1.0 \mathrm{~g} / \mathrm{L}$ to $30 \mathrm{~g} / \mathrm{L}$ and is shown in Fig. 3. The experimental data explained that the percent removal of metal biosorption has linear relationship with raising the amount of CMSCL. Beyond $15 \mathrm{~g} / \mathrm{L}$ up to $30 \mathrm{~g} / \mathrm{L}$ the percent biosorption was negligible. It was concluded that dosage of CMSCL of $5 \mathrm{~g} / \mathrm{L}$ was further used as an optimum amount for maximum removal of $\mathrm{Pb}$ (II) and Cd (II) ions. The experimental result clearly elaborates that biosorption increases by raising biomass sites. The biosorption capability becomes nearly remain same above the optimum dose value which is due to high biosorbent dose resulted in the biosorbent aggregation. The interference phenomenon may be happening between active binding sites at higher biosorbent dose or insufficient heavy metal ions in the aqueous system with respect to available active binding sites. It is known that hydrogen ions will react with heavy metal ions and therefore decreases the interactive relationship of $\mathrm{Pb}$ (II) and Cd (II) ions with the biomass (Hanafiah et al., 2009). Moreover similar reports were achieved for the removal of $\mathrm{Cd}$ (II) ions from aqueous system by Saccharomyces cerevisiae. Therefore, the optimal amount of biosorbent was taken as $5 \mathrm{~g} / \mathrm{L}$ for further research.

Study of initial metal ions concentration. Initial metal concentration is considered to be a necessary parameters of the biosorption study. The initial metal concentration was studied for $\mathrm{Pb}$ (II) and $\mathrm{Cd}$ (II) ions varied from 20 to $700 \mathrm{ppm}$. The CMSCL was taken $5 \mathrm{~g} / \mathrm{L}$ by keeping constant other parameters. Figure 4 shows that the metal absorption capability on CMSCL increases when percent

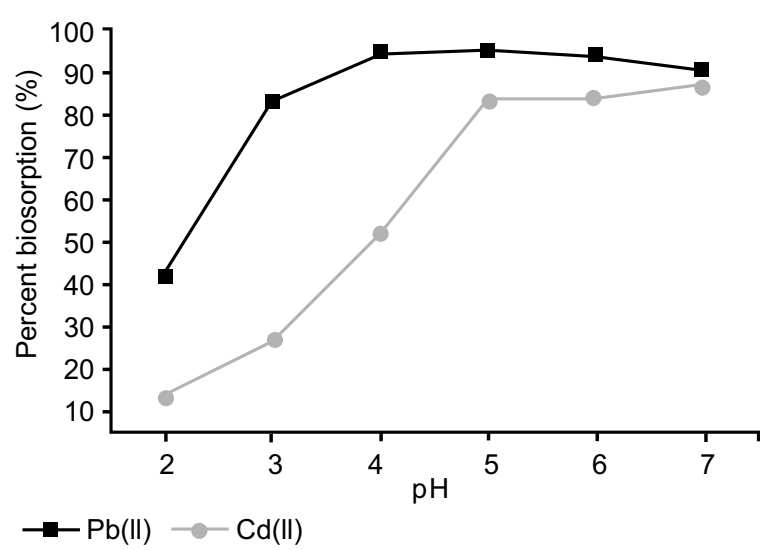

Fig. 2. Ionic precipitation of metal hydroxides occurs at higher $\mathrm{pH}$ value.

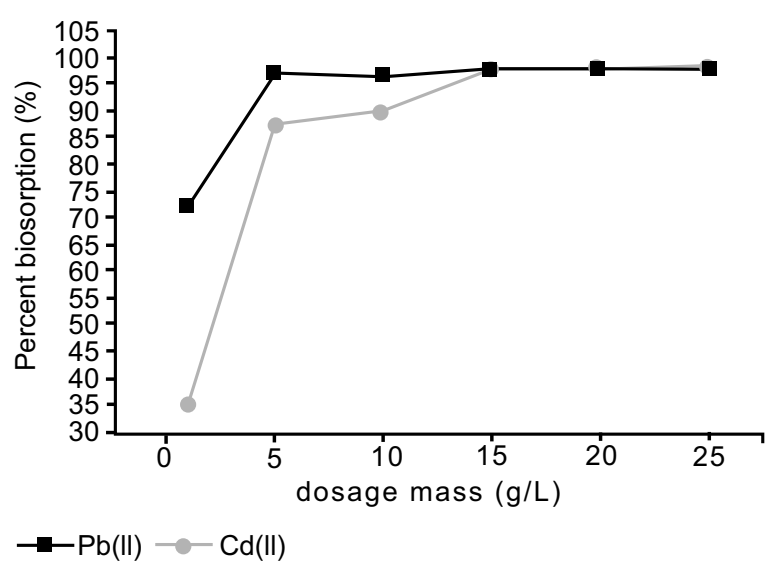

Fig. 3. Biomass dose for the removal of $\mathrm{Pb}$ (II) and $\mathrm{Cd}$ (II) ions onto CMSCL. 
biosorption decreases with the increasing initial concentration of $\mathrm{Pb}$ (II) and $\mathrm{Cd}$ (II) ions. Biosorption capacity Increase were due to increasing in concentration (Rao et al., 2011). Biosorbent ability of CMSCL leaves increases by raising the metal ion concentration. At lower concentration of heavy metal ions, it is observed that biosorption reached up to near hundred percent.

Effect of initial concentration on the biosorption of $\mathrm{Pb}$ (II) and Cd (II) ions onto CMSCL (experimental parameters for $\mathrm{Pb}$ (II) and $\mathrm{Cd}$ (II): $\mathrm{pH} 6.0$ and 7.0, contact time 120 and $60 \mathrm{~min}$, solution $100 \mathrm{~mL}$, biomass $0.5 \mathrm{~g}$, temperature 50 and $40{ }^{\circ} \mathrm{C}$, shaking speed $180 \mathrm{rpm}$ ) shows in Fig. 4.

Study of contact time. Contact time is considered to be the crucial parameter for the study of heavy metals biosorption by CMSCL biomass. When the contact time increases the metal biosorption also increases linearly shown in Fig. 5. Initially rapid removal of $\mathrm{Pb}$ (II) and $\mathrm{Cd}$ (II) ions occur in which maximum absorption occurs and becomes slow and continued until equilibrium was attained. The first step was fast due to the maximum available spaces on biosorbent surface. The process becomes slower in the second step when the surface of chemically modified Syzygium cumini leaves (CMSCL) was deposited by metal ions. Therefore, the optimum time for $\mathrm{Pb}$ (II) and $\mathrm{Cd}$ (II) ions biosorption was considered as $120 \mathrm{~min}$ and $60 \mathrm{~min}$ respectively for further research (Rao et al., 2011).

Temperature effect. Temperature is an important parameter studied for the removal of $\mathrm{Pb}$ (II) and Cd (II)

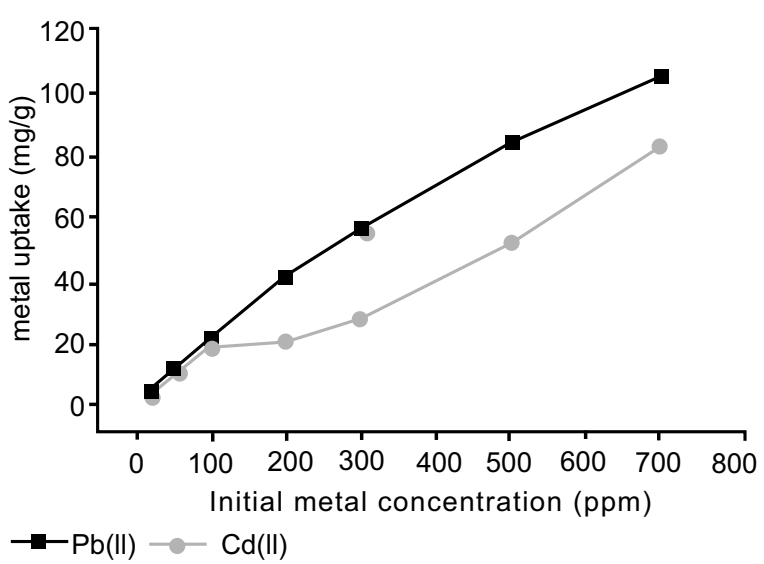

Fig. 4. Effect of initial concentration on the biosorption of $\mathrm{Pb}$ (II) and $\mathrm{Cd}$ (II) ions onto CMSCL. ions. It was varied from 298 to $348 \mathrm{~K}$, while all other parameters remain unchanged. Figure 6 shows when the temperature increases the nature of biomass changes and biosorption capacity increases and reaches to further minimum change at $348 \mathrm{~K}$. The relationship of temperature and biosorption of metal ions is given in Fig. 6 which shows a decrease in the removal of $\mathrm{Pb}$ (II) and

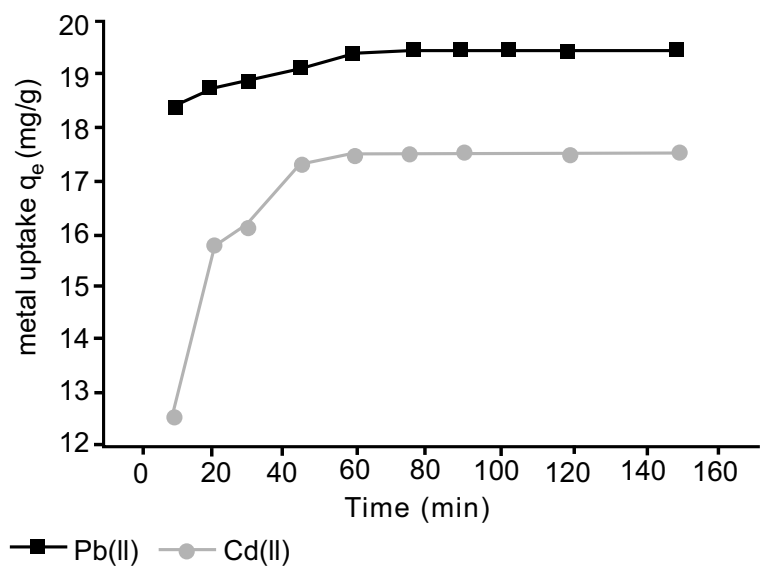

Fig. 5. Contact time study on the removal of $\mathrm{Pb}$ (II) and Cd (II) ions onto CMSCL (experimental parameters for $\mathrm{Pb}$ (II) and Cd (II): $\mathrm{pH} 6.0$ and 7.0, biomass $0.5 \mathrm{~g}$, solution $100 \mathrm{~mL}$, initial con. $100 \mathrm{mg} / \mathrm{L}$, temperature 50 and $40{ }^{\circ} \mathrm{C}$, shaking speed $180 \mathrm{rpm})$.

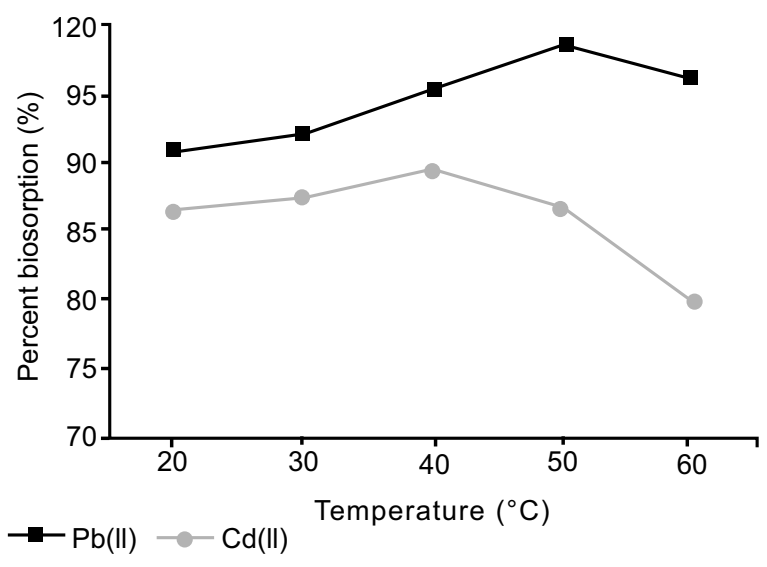

Fig. 6. Temperature study on the removal of $\mathrm{Pb}$ (II) and Cd (II) ions onto CMSCL (experimental parameters for $\mathrm{Pb}$ (II) and $\mathrm{Cd}$ (II): pH 6.0 and 7.0, biomass $0.5 \mathrm{~g}$, solution $100 \mathrm{~mL}$, initial con. $100 \mathrm{mg} / \mathrm{L}$, contact time 120 and $60 \mathrm{~min}$ and shaking speed $180 \mathrm{rpm}$ ). 
Cd (II) ions with the regular increase in temperature which may be due to the destruction of active sites in the surface of biosorbent. The optimum temperature for the removal of $\mathrm{Pb}$ (II) and $\mathrm{Cd}$ (II) ions was $50{ }^{\circ} \mathrm{C}$ and $40{ }^{\circ} \mathrm{C}$, respectively (Sari and Tuzen, 2009).

Biosorption kinetics. Kinetics studies is important for the evaluation of batch biosorption process. It is necessary to get fundamental information about the rate by which absorption occurs on the CMSCL biomass. To study the chemical kinetics for biosorption for $\mathrm{Pb}$ (II) and Cd (II) ions, the pseudo-first order (Ho, 2009) and pseudo-second order kinetics models Amegrissi et al. (2013) were applied on the experimentally obtained data.

The pseudo-first order kinetic model was presented by Lagergren in 1898.

$$
\begin{aligned}
& \mathrm{d}_{\mathrm{q}} / \mathrm{d}_{\mathrm{t}}=\mathrm{k}_{1}\left(\mathrm{q}_{\mathrm{e}}-\mathrm{q}_{\mathrm{t}}\right) \\
& \mathrm{q}_{\mathrm{t}}=\mathrm{q}_{\mathrm{e}}\left(1-\mathrm{e}^{-\mathrm{K} 1 \mathrm{t}}\right) \ldots .
\end{aligned}
$$

The $\mathrm{q}_{\mathrm{e}}(\mathrm{mg} / \mathrm{g})$ is for metal ion concentrations at equilibrium and $\mathrm{q}_{\mathrm{t}}(\mathrm{mg} / \mathrm{g})$ is metal ion concentration at any time $\mathrm{t}$. The $\mathrm{k}_{1} / \mathrm{min}$ is the rate constant for $1^{\text {st }}$ order.

Lagergren pseudo-first order models are not suitable for the biosorption kinetics study.

The pseudo-second order kinetic models presented by Ho for the biosorption in the equation form is given below:

$$
\begin{aligned}
& \mathrm{dq}_{\mathrm{t}} / \mathrm{d}_{\mathrm{t}}=\mathrm{k}_{2}\left(\mathrm{q}_{\mathrm{e}}-\mathrm{q}_{\mathrm{t}}\right)^{2} \ldots \ldots \\
& \mathrm{q}_{\mathrm{t}}=\mathrm{q}_{\mathrm{e}} \quad \mathrm{q}_{\mathrm{e}} \mathrm{K}_{2} \mathrm{t} / 1+\mathrm{q}_{\mathrm{e}} \mathrm{K}_{2} \mathrm{t}
\end{aligned}
$$

where:

$\mathrm{K}_{2}$ is the second order kinetic equilibrium rate constant $(\mathrm{g} / \mathrm{mg} / \mathrm{min})$. The $\mathrm{q}_{\mathrm{t}}(\mathrm{mg} / \mathrm{g})$ and $\mathrm{q}_{\mathrm{e}}(\mathrm{mg} / \mathrm{g})$ for the biosorption at time " $\mathrm{t}$ " and the biosorption at equilibrium.

The equilibrium capacity $\mathrm{q}_{\mathrm{e}}$, rate constant $\mathrm{k}_{2}$ and correlation coefficient $\left(\mathrm{R}^{2}\right)$ are given in Table 2 . The comparison of the experimental work with kinetic model's data confirmed a good correlation coefficient $\left(\mathrm{R}^{2}\right)$ and was greater than 0.999 . The value of $\mathrm{q}_{\mathrm{e}}$ obtained is in close agreement with pseudo-second order kinetics model. The kinetic model is more suitable to predict kinetic nature with chemical biosorption being occur in the rate determining step. It was concluded on the bases of correlation coefficient $\left(\mathrm{R}^{2}\right)$ that the removal of $\mathrm{Pb}$ (II) and $\mathrm{Cd}$ (II) ions by using CMSCL was chemisorption and followed pseudo second kinetics model.
Table 2. Kinetic study of pseudo second order for removal of $\mathrm{Pb}(\mathrm{II})$ and $\mathrm{Cd}(\mathrm{II})$ ions

\begin{tabular}{lllll}
\hline \hline Metals & & \multicolumn{3}{c}{ Pseudo second order } \\
\cline { 3 - 5 } & $\mathrm{C}_{0}$ & $\mathrm{~K}_{2}$ & $\mathrm{q}_{\mathrm{e}}$ & $\mathrm{R}_{2}$ \\
& $(\mathrm{mg} / \mathrm{L})$ & $(\mathrm{g} / \mathrm{mg} / \mathrm{min})$ & $\mathrm{mg} / \mathrm{g}$ & \\
\hline $\mathrm{Pb}(\mathrm{II})$ & 100 & 0.01968 & 12.269 & 0.999 \\
$\mathrm{Cd}$ (II) & 100 & 0.01776 & 13.960 & 0.999 \\
\hline \hline
\end{tabular}

Adsorption isotherms at equilibrium. At the same temperature and equilibrium condition biosorption explains the relationship between per unit mass of the adsorbent and the amount of the adsorbate adsorbed. The equilibrium system at constant temperature is established to check the batch biosorption process in batch dynamics. Important information were obtained from adsorption isotherm that reveals the occurrence of absorption. The sorbent and sorbate interaction determine its distribution between liquid and solid phases.

According to Langmuir adsorption isotherm, "a fixed number of specific homogenous places are available at the surface of adsorbent on which reversible monolayer adsorption takes place without the lateral interaction among the adsorbate species" (Sari and Tuzen, 2009).

Langmuir equation at constant temperature is given as:

$$
\mathrm{q}_{\mathrm{e}}=\mathrm{q}_{\max } \mathrm{b} \mathrm{C}_{\mathrm{e}} / 1+\mathrm{b} \mathrm{C}_{\mathrm{e}}
$$

After solving we get the linear equation as:

$$
\mathrm{C}_{\mathrm{e}} / \mathrm{q}_{\mathrm{e}}=1 / \mathrm{q}_{\max } \mathrm{b}+\mathrm{C}_{\mathrm{e}} / \mathrm{q}_{\max }
$$

At equilibrium, the quantity of adsorbate adsorbed per unit weight of biomass is given by $\mathrm{q}_{\mathrm{e}}$ (adsorbate in $\mathrm{mg}$ / adsorbent in $\mathrm{g}$ ). At equilibrium condition the adsorbate present in the aqueous solution after the process of biosorption is given by $\mathrm{C}_{\mathrm{e}}(\mathrm{mg} / \mathrm{L})$. The $\mathrm{q}_{\max }(\mathrm{mg} / \mathrm{g})$ shows highest adsorption ability of the adsorbent while b (L/mg) shows the experimental Langmuir constant for adsorption. The $b(\mathrm{~L} / \mathrm{mg})$ is also relationship of ability and free energy of binding places available. The Langmuir adsorption isotherm perfectly describes the present biosorption data.

According to Freundlich adsorption isotherm "adsorption of molecules on available active places assumes a multilayer sorption" (Sari and Tuzen, 2009) Mathematically, Freundlich adsorption isotherm equation is given as:

$$
\mathrm{q}_{\mathrm{e}}=\mathrm{k}_{\mathrm{F}}\left(\mathrm{C}_{\mathrm{e}}\right)^{1 / \mathrm{n}}
$$


Linear equation of above equation can be expressed as:

$$
\ln \mathrm{q}_{\mathrm{e}}=1 / \mathrm{n} \ln \mathrm{C}_{\mathrm{e}}+\ln \mathrm{k}_{\mathrm{F}}
$$

where:

$\mathrm{C}_{\mathrm{e}}(\mathrm{mg} / \mathrm{L})$ is the equilibrium concentration of adsorbate in the aqueous solution. At equilibrium, the $\mathrm{q}_{\mathrm{e}}(\mathrm{mg} / \mathrm{g})$ is the amount of adsorbate adsorbed per unit mass of biosorbent. The $\mathrm{K}_{\mathrm{F}}$ is adsorption coefficient which shows the biosorption ability and $\mathrm{n}$ is associated with the amount of biosorption. High values of $n$ and $K_{F}$ and lower value of $\mathrm{R}^{2}$ showed that Freundlich isotherm does not applicable to the present research data given in Table 3.

Adsorption thermodynamics. Biosorption of $\mathrm{Pb}$ (II) and Cd (II) ions are generally written by the following reversible process:

Metal (II) ions in aqueous solution $\leftarrow \rightarrow$ metal (II) ions-biomass

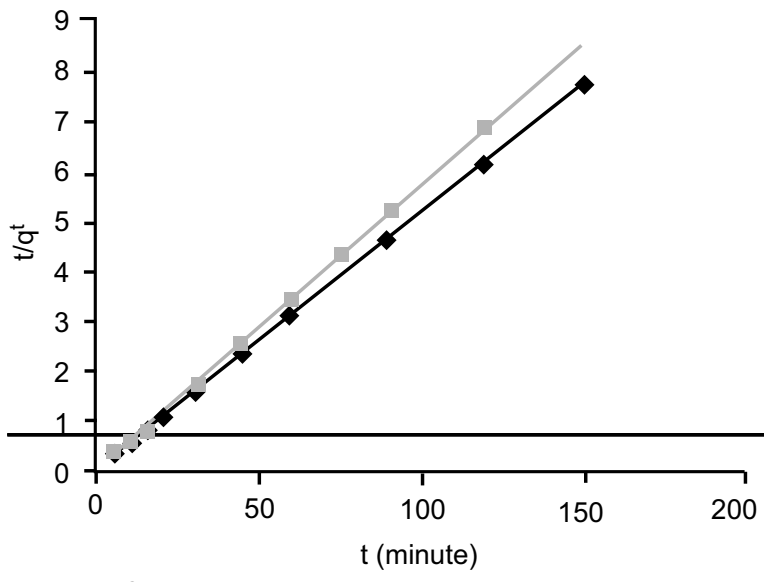

$-\mathrm{Pb} \backsim \mathrm{Cd}$

Fig. 7. Pseudo-second order kinetics plot for the removal of $\mathrm{Pb}$ (II) and $\mathrm{Cd}$ (II) ions by using CMSCL.

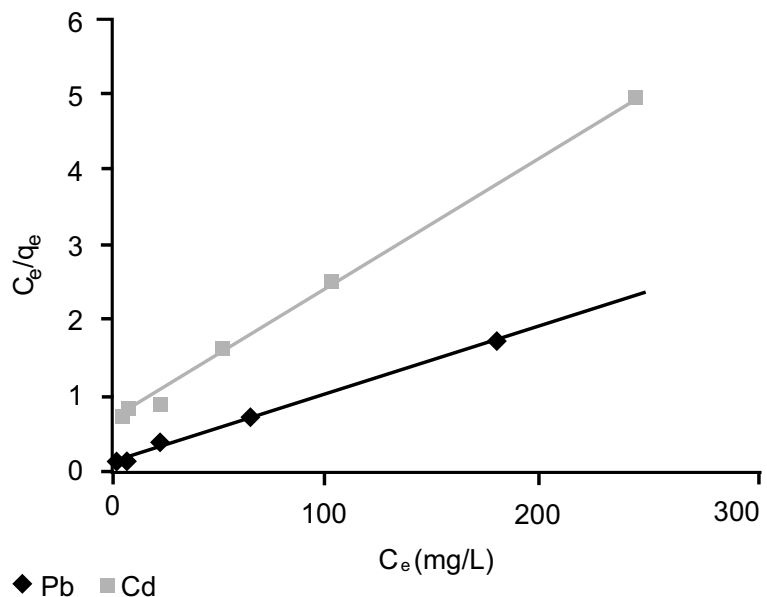

Fig. 8. Langmuir plot for the removal of $\mathrm{Pb}$ (II) and Cd (II) ions onto CMSCL.

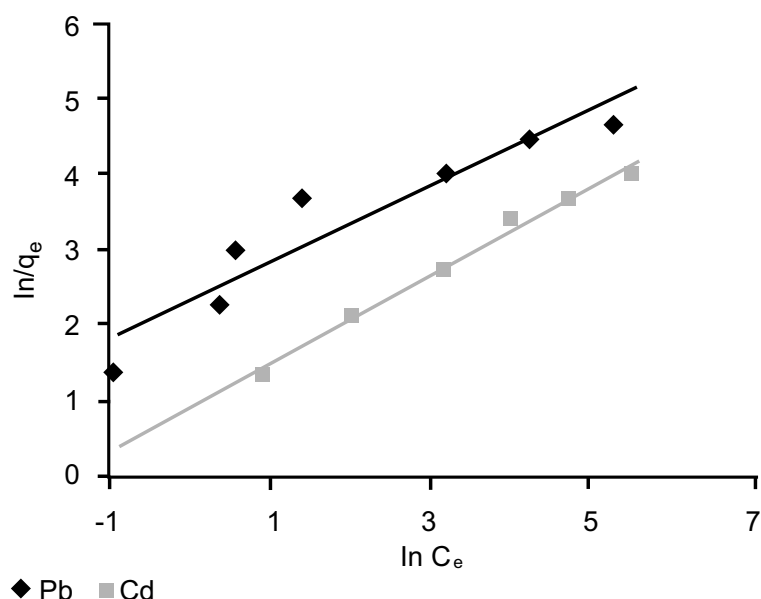

Fig. 9. Freundlich plot for the removal of $\mathrm{Pb}$ (II) and Cd (II) ions onto CMSCL.

Thermodynamic parameters are used to study the physical or chemical nature and feasibility of the biosorption process. It is also important to investigate whether the process is exothermic or endothermic. The changes in enthalpy $\left(\Delta \mathrm{H}^{\circ}\right)$, Gibbs free energy $\left(\mathrm{G}^{\circ}\right)$ and

Table 3. Langmuir, Freundlich and Temkin isotherm correlation coefficients and constants for the removal $\mathrm{Pb}$ (II) and $\mathrm{Cd}$ (II) ions by CMSCL

\begin{tabular}{|c|c|c|c|c|c|c|c|c|c|c|}
\hline \multirow{2}{*}{ Metals } & \multirow[b]{2}{*}{$\begin{array}{l}\mathrm{C}_{0} \\
(\mathrm{mg} / \mathrm{L})\end{array}$} & \multicolumn{3}{|c|}{ Langmuir model } & \multicolumn{3}{|c|}{ Freundlich model } & \multicolumn{3}{|c|}{ Temkin model } \\
\hline & & $\begin{array}{l}\mathrm{q}_{\max } \\
(\mathrm{mg} / \mathrm{g})\end{array}$ & $\begin{array}{l}\mathrm{b} \\
(\mathrm{mg} / \mathrm{L})\end{array}$ & $\mathrm{R}^{2}$ & $\begin{array}{l}\mathrm{n} \\
(\mathrm{g} / \mathrm{L})\end{array}$ & $\begin{array}{l}\mathrm{K}_{\mathrm{F}} \\
(\mathrm{g} / \mathrm{L})\end{array}$ & $\mathrm{R}^{2}$ & $\begin{array}{l}\mathrm{K}_{\mathrm{T}} \\
(\mathrm{g} / \mathrm{L})\end{array}$ & $\begin{array}{l}\mathrm{b}_{\mathrm{T}} \\
(\mathrm{J} / \mathrm{mol})\end{array}$ & $\mathrm{R}^{2}$ \\
\hline $\mathrm{Pb}$ (II) & 100 & 109.89 & 0.0760 & 0.9931 & 1.956 & 213.45 & 0.8879 & 1.958 & 144.44 & 0.9693 \\
\hline Cd (II) & 100 & 57.14 & 57.14 & 0.9956 & 1.699 & 7.80 & 0.9695 & 0.366 & 239.65 & 0.9577 \\
\hline
\end{tabular}


entropy $\left(\Delta S^{\circ}\right)$ were determined by applying the Van't Hoff's equations:

$$
\begin{aligned}
& \mathrm{K}_{\mathrm{D}}=\mathrm{q}_{\mathrm{e}} / \mathrm{C}_{\mathrm{e}} \ldots \ldots \ldots \ldots \ldots \ldots \ldots \ldots \ldots \ldots \ldots \ldots \ldots \ldots \\
& \Delta \mathrm{G}^{0}=-\mathrm{RT} \ln \mathrm{K}_{\mathrm{D}} \ldots \ldots \ldots \ldots \ldots \ldots \\
& \ln \mathrm{K}_{\mathrm{D}}=\Delta \mathrm{S}^{\circ} \mathrm{R}-\Delta \mathrm{H}^{\circ} / \mathrm{RT}
\end{aligned}
$$

$K_{D}$ of Van't Hoff's plot is a function of 1/T gives a straight line shown in Fig. 11. The $\Delta \mathrm{S}^{\circ}$ and $\Delta \mathrm{H}^{\circ}$ were calculated from intercept and slope respectively.

The calculated Gibbs free energy $\left(\Delta \mathrm{G}^{\circ}\right)$ are -2.138 , $-2.174,-2.245,-2.316 \mathrm{KJ} / \mathrm{mol}$ for $\mathrm{Pb}$ (II) ions and $-0.325,-0.334,-0.345,-0.356 \mathrm{KJ} / \mathrm{mol}$ for $\mathrm{Cd}$ (II) ions

Table 4. Thermodynamics conditions for removal of $\mathrm{Pb}$ (II) and Cd (II) ions onto CMSCL

\begin{tabular}{lllllll}
\hline \hline Metals & $\Delta \mathrm{H}$ & $\Delta \mathrm{S}$ & \multicolumn{4}{c}{$\Delta \mathrm{G}(\mathrm{Kj} / \mathrm{mol})$} \\
\cline { 4 - 7 } & $(\mathrm{Kj} / \mathrm{mol})$ & $(\mathrm{Kj} / \mathrm{mol})$ & $298 \mathrm{~K}$ & $303 \mathrm{~K}$ & $313 \mathrm{~K}$ & $323 \mathrm{~K}$ \\
\hline $\mathrm{Pb}(\mathrm{II})$ & -12.158 & 7.136 & -2.138 & -2.174 & -2.245 & -2.316 \\
$\mathrm{Cd}(\mathrm{II})$ & -2.100 & 1.0964 & -0.325 & -0.334 & -0.345 & -0.356 \\
\hline \hline
\end{tabular}

removal at $298 \mathrm{~K}, 303 \mathrm{~K}, 313 \mathrm{~K}, 323 \mathrm{~K}$, respectively. The Table 4 shows the values of $\Delta \mathrm{H}^{\circ}, \Delta \mathrm{S}$ and $\Delta \mathrm{G}^{\circ}$. The parameter $\Delta \mathrm{H}^{\circ}$ was found to be $-12.157 \mathrm{KJ} / \mathrm{mol}$ and $-2.100 \mathrm{KJ} / \mathrm{mol}$ for the removal $\mathrm{Pb}$ (II) and $\mathrm{Cd}$ (II) ions, respectively. The negative value of $\Delta \mathrm{H}^{\circ}$ exhibits that the $\mathrm{Pb}$ (II) and $\mathrm{Cd}$ (II) ions removal on to CMSCL was exothermic in nature. The was achieved value for $\Delta \mathrm{S}^{\circ}$ was $7.135 \mathrm{~J} / \mathrm{mol} \mathrm{K}$ for the removal of $\mathrm{Pb}$ (II) ions and $1.0964 \mathrm{~J} / \mathrm{mol} \mathrm{K}$ for of $\mathrm{Cd}$ (II) ions removal. The positive value of $\Delta \mathrm{S}^{\circ}$ suggest that biosorption mechanism was favourable (Singh et al., 2006). The negative values of $\Delta \mathrm{G}^{\circ}$ shows the decline in biosorption feasibility with increases in temperature, nature of chemical biosorption and spontaneous nature of biosorption process (Krishna and Venkateswarlu, 2011).

Comparative biosorption capacity. As shown in Table 5, CMSCL is a cheap and abundantly available alternative chemically modified Syzygium cumini leaves which has higher biosorption capability than many other

\begin{tabular}{|c|c|c|c|}
\hline Biomass & $\begin{array}{l}\mathrm{q}_{\max }(\mathrm{mg} / \mathrm{g}) \\
\text { for } \mathrm{Pb}(\mathrm{II}) \text { ions }\end{array}$ & $\begin{array}{l}\mathrm{q}_{\max }(\mathrm{mg} / \mathrm{g}) \\
\text { for } \mathrm{Cd}(\mathrm{II}) \text { ions }\end{array}$ & References \\
\hline Ulva lactuca & 34.7 & 29.2 & (Krishnani et al., 2008) \\
\hline Phanerochaete chrysosporium & 69.8 & 23.0 & (Jiemtaweeboon et al., 2007 \\
\hline Lactarius scrobiculatus & 56.2 & 53.1 & (Anayurt et al., 2009b) \\
\hline Peels of Banana & 2.18 & 5.71 & (Anwar et al., 2010b) \\
\hline Amanita rubescens & 38.4 & 27.3 & (Sari and Tuzen, 2009) \\
\hline Mucor rouxii & - & 20.3 & (Saltali et al., 2007) \\
\hline Phanerochaete chrysosporium & - & 15.2 & (Shohreh et al., 2016) \\
\hline Rhizopus Arrhizus & - & 26.8 & (Alimohamadi et al., 2005) \\
\hline Streptomyces noursei & - & 3.4 & (Mattuschka and Straube, 2010) \\
\hline Mucor rouxii & - & 20.3 & (Yan and Viraraghavan, 2010) \\
\hline Moringa oleifera tree leaves & 209.40 & - & (Reddy et al., 2010a) \\
\hline Ulmus carpinifolia leaves & 201.10 & - & (Sangi et al., 2008) \\
\hline Fraxinus excelsior leaves & 172.00 & - & (Sangi et al., 2011) \\
\hline Xanthat rubber leaf powder & 166.70 & - & (Khalir et al., 2011) \\
\hline Sludge of rose petals & 87.70 & - & (Nasir et al., 2007 \\
\hline Tea waste & 65.00 & - & (Amarasinghe and Williams, 2007) \\
\hline Rubber leaf powder & 46.70 & - & (Hanafiah et al., 2006) \\
\hline Sago waste & 46.60 & - & (Auldry et al., 2009) \\
\hline Tree fern & 40.00 & - & (Driscoll et al., 2003) \\
\hline Ficus religiosa leaves & 37.45 & - & (Kazmi et al., 2015) \\
\hline Groundnut hull & 31.54 & - & (Qaiser et al., 2009) \\
\hline Rice husk ash & 12.60 & - & (Feng et al., 2004) \\
\hline Lalang leaf powder & 5.89 & - & (Abdus-Salam, 2012) \\
\hline Tobacco stem & 5.54 & - & (Wei et al., 2008) \\
\hline CMSCL & 109.89 & 57.14 & This study \\
\hline
\end{tabular}
biomasses.

Table 5. Comparative study of maximum biosorption capability of CMSCL with other low-cost biomasses 


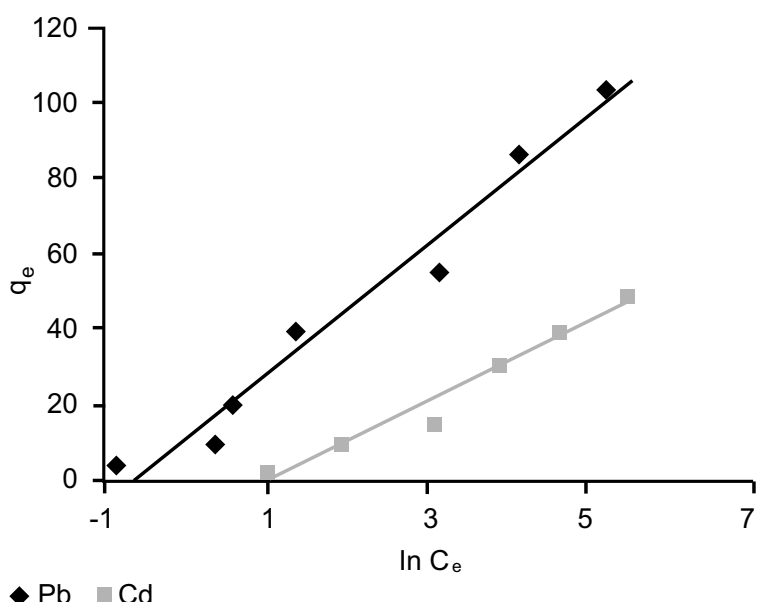

Fig. 10. Temkin plot for the removal of $\mathrm{Pb}$ (II) and $\mathrm{Cd}$ (II) ions onto CMSCL.

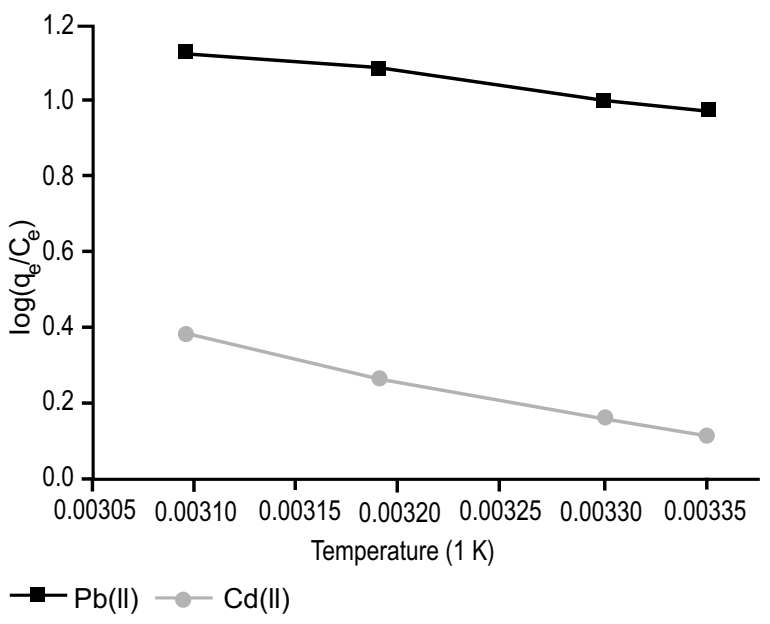

Fig. 11. The Van't Hoff's plot for the removal of $\mathrm{Pb}$ (II) and Cd (II) ions onto CMSCL (experimental parameters for $\mathrm{Pb}$ and $\mathrm{Cd}$ (II) ions: $\mathrm{pH} 6.0$ and 7.0, biomass $0.5 \mathrm{~g}$, solution $100 \mathrm{~mL}$, initial con. $100 \mathrm{mg} / \mathrm{L}$, contact time 120 and 60 min and Agitation speed $180 \mathrm{rpm}$ ).

\section{Conclusion}

The present study proved that CMSCL could be efficiently used as an effective and alternative biosorbent for the removal of $\mathrm{Pb}$ (II) and $\mathrm{Cd}$ (II) ions from aqueous solution. The operating conditions, $\mathrm{pH}$ of the solution, biosorbent dosage, initial metal concentration, temperature and contact time were thoroughly studied for biosorption efficiency. The maximum removal capacity of $\mathrm{Pb}$ (II) and $\mathrm{Cd}$ (II) ions was $109.89 \mathrm{mg} / \mathrm{g}$ and 57.14 $\mathrm{mg} / \mathrm{g}$ at optimum $\mathrm{pH} 6.0$ and $\mathrm{pH} 7.0$, contact time of $120 \mathrm{~min}$ and $60 \mathrm{~min}$ and temperature $50^{\circ} \mathrm{C}$ and $40^{\circ} \mathrm{C}$, respectively. The kinetic studies declared the biosorption of $\mathrm{Pb}$ (II) and $\mathrm{Cd}$ (II) ions onto CMSCL biomass properly followed the pseudo-second order kinetic model. Thermodynamic data exhibits that the process of biosorption of $\mathrm{Pb}$ (II) and $\mathrm{Cd}$ (II) ions onto CMSCL was spontaneous, feasible and exothermic. Langmuir isotherm successfully interpreted the process of biosorption. Taking into evaluation of the present works, it can be concluded that CMSCL is good biomass having a high capacity for removal of $\mathrm{Pb}$ (II) and $\mathrm{Cd}$ (II) ions from aqueous solution and industrial effluents. Furthermore, it can be considered as low-cost alternative biomass for the biosorption of $\mathrm{Pb}$ (II) and $\mathrm{Cd}$ (II) ions containing wastewater.

\section{Acknowledgment}

We are thankful to PCSIR Labs Complex Peshawar, Centralized Resource Laboratories (CRL) University of Peshawar and Higher Education Commission of Pakistan (HEC) for their technical and financial support.

Conflict of Interest. The authors declare have no conflict of interest.

\section{References}

Abdus-Salam, N. 2012. Potential application of termite mound for adsorption and removal of $\mathrm{Pb}$ (II) from aqueous solutions. Journal of the Iranian Chemical Society, 9: 373-382.

Adelaja, O.A., Bankole, A.C., Oladipo, M.E., Lene, B.L. 2019. Biosorption of $\mathrm{Hg}$ (II) ions, Congo red and their binary mixture using raw and chemically activated mango leaves. International Journal of Energy and Water Resources, 3: 1-12.

Agency, E.P. 2002. National primary drinking water regulations: Long term 1 enhanced surface water treatment rule. Final Rule, Federal Register, 67: 1811.

Alimohamadi, M., Abolhamd, G., Keshtkar, A. 2005. $\mathrm{Pb}$ (II) and $\mathrm{Cu}$ (II) biosorption on Rhizopus arrhizus modeling mono- and multi-component systems. Minerals Engineering, 18: 1325-1330.

Amarasinghe, B., Williams, R. 2007. Tea waste as a low cost adsorbent for the removal of $\mathrm{Cu}$ and $\mathrm{Pb}$ 
from wastewater. Chemical Engineering Journal, 132: 299-309.

Amegrissi, F., Maghri, I., Elkouali, M., Kenz, A., Salouhi, M., Talbi, M. 2013. Heavy metal uptake by agro based waste materials. Global Journal of Science Frontier Research Environment \& Earth Science, 13: 1-5.

Anayurt, R.A., Sari, A., Tuzen, M. 2009a. Equilibrium, thermodynamic and kinetic studies on biosorption of $\mathrm{Pb}$ (II) and $\mathrm{Cd}$ (II) from aqueous solution by macrofungus (Lactarius scrobiculatus) biomass. Chemical Engineering Journal, 151: 255-261.

Anayurt, R.A., Sari, A., Tuzen, M. 2009b. Equilibrium, thermodynamic and kinetic studies on biosorption of $\mathrm{Pb}$ (II) and $\mathrm{Cd}$ (II) from aqueous solution by macrofungus (Lactarius scrobiculatus) biomass. Chemical Engineering Journal, 151: 255-261.

Anwar, J., Shafique, U., Salman, M., Dar, A., Anwar, S. 2010a. Removal of $\mathrm{Pb}$ (II) and Cd (II) from water by adsorption on peels of banana. Bioresource Technology, 101: 1752-1755.

Anwar, J., Shafique, U., Waheed-uz-Zaman, Salman, M., Dar, A., Anwar, S. 2010b. Removal of Pb (II) and Cd (II) from water by adsorption on peels of banana. Bioresource Technology, 101: 1752-1755.

Auldry, C.P., Ahmed, O.H., Nik Muhamad, A.M., Nasir, H.M., Jiwan, M. 2009. Production of potassium and calcium hydroxide, compost and humic acid from sago (Metroxylon sagu) waste. American Journal of Environmental Sciences, 5: 664-668.

Bozkurt, H.A.C., Geyik, F. 2013. Use of artificial neural networks and genetic algorithms for prediction of sorption of an azo-metal complex dye onto lentil straw. Bioresource Technology, 129: 396-401.

Chagas, V.T., França, L.M., Malik, S., Paes, A.M.A. 2015. Syzygium cumini (L.) skeels: a prominent source of bioactive molecules against cardiometabolic diseases, Front Pharmacol, 6: 259.

Cimá-Mukul, C., Abdellaoui, Y., Abatal, M., Vargas, J., Santiago, A.A., Barrón-Zambrano, J.A.J.B.C. 2019. Eco-efficient biosorbent based on Leucaena leucocephala residues for the simultaneous removal of $\mathrm{Pb}$ (II) and $\mathrm{Cd}$ (II) Ions from water system; Sorption and Mechanism. Bioinorganic Chemistry and Applications, 2019, 13 pp.

Driscoll, C.T., Whitall, D., Aber, J., Boyer, E., Castro, M., Cronan, C., Goodale, C.L., Groffman, P., Hopkinson, C., Lambert, K. 2003. Nitrogen pollution in the northeastern united states: sources, effects, and management options. Bioscience, 53: 357 374.

Edokpayi, J., Odiyo, J., Msagati, T., Popoola, E.J.S. 2015. A novel approach for the removal of lead (II) ion from wastewater using mucilaginous leaves of Diceriocaryum eriocarpum plant. Sustainability, 7: 14026-14041.

Feng, Q., Lin, Q., Gong, F., Sugita, S., Shoya, M. 2004. Adsorption of lead and mercury by rice husk ash. Journal of Colloid and Interface Science, 278: 1-8.

Gupta, S., Sharma, S., Kumar, A.J.W.S. 2019. Biosorption of Ni (II) ions from aqueous solution using modified Aloe barbadensis Miller leaf powder. Applied Water Science, 9: 11.

Hanafiah, M.A.K.M., Zakaria, H., Ngah, W.S.W. 2009. Preparation, characterization, and adsorption behaviour of $\mathrm{Cu}$ (II) ions onto alkali-treated weed (Imperata cylindrica) leaf powder. Water Air and Soil Pollution, 201: 43-53.

Hanafiah, M.A.K.M., Shafiei, S., Harun, M.K., Yahya, M.Z.A. 2006. Kinetic and thermodynamic study of $\mathrm{Cd}^{2+}$ adsorption onto rubber tree (Hevea brasiliensis) leaf powder, Materials Science Forum, 217-221.

Ho, Y.S. 2009. Comment on "thermodynamics and kinetics of adsorption of $\mathrm{Cu}$ (II) onto waste iron oxide". Journal of Hazardous Materials, 162: 539539.

Jiemtaweeboon, S., Shirasuna, K., Nitta, A., Kobayashi, A., Schuberth, H.J., Shimizu, T., Miyamoto, A. 2007. Evaluation of the marine algae Ulva fasciata and Sargassum sp. for the biosorption of $\mathrm{Cu}$ (II) from aqueous solutions. Bioresource Technology, 98: 452-455.

Kazmi, M., Ramzan, N., Feroze, N., Almas, Q., Zafar, M., Saeed, Z. 2015. Removal of zinc and copper from contaminated water using Ficus religiosa leaves: kinetic, equilibrium and mechanistic studies. Pakistan Journal of Agricultural Sciences, 52: 619-625.

Khalir, W., Hanafiah, M., So'ad, S., Ngah, W. 2011. Adsorption behaviour of $\mathrm{Pb}$ (II) onto xanthated rubber (Hevea brasiliensis) leaf powder. Polish Journal of Chemical Technology, 13: 84-88.

Khokhar, A., Siddique, Z., Misbah. 2015. Removal of heavy metal ions by chemically treated Melia 
azedarach L. Leaves. Journal of Environmental Chemical Engineering, 2: 944-952.

Krishna, B., Venkateswarlu, P. 2011. Influence of Ficus religiosa leaf powder on bisorption of cobalt. Indian Journal of Chemical Technology, 8: 381390.

Krishnani, K.K., Meng, X., Christodoulatos, C., Boddu, V.M. 2008. Biosorption mechanism of nine different heavy metals onto biomatrix from rice husk. Journal of Hazardous Materials, 153: 1222-1234.

Mattuschka, B., Straube, G. 2010. Biosorption of metals by a waste biomass. Journal of Chemical Technology and Biotechnology, 58: 57-63.

Nasir, M.H., Nadeem, R., Akhtar, K., Hanif, M.A., Khalid, A.M. 2007. Efficacy of modified distillation sludge of rose (Rosa centifolia) petals for lead (II) and zinc (II) removal from aqueous solutions. Journal of Hazardous Materials, 147: 1006-1014.

Ngah, W.S.W., Hanafiah, M.A.K.M. 2008. Removal of heavy metal ions from wastewater by chemically modified plant wastes as adsorbents: A review. Bioresource Technology, 99: 3935-3948.

Priyantha, N., Kotabewatta, P.J.A.W.S. 2019. Biosorption of heavy metal ions on peel of Artocarpus nobilis fruit: 1-Ni (II) sorption under static and dynamic conditions. Applied Water Science, 9: 37.

Qaiser, S., Saleemi, A.R., Umar, M. 2009. Biosorption of lead (II) and chromium (VI) on groundnut hull: equilibrium, kinetics and thermodynamics study. Electronic Journal of Biotechnology, 12: 3-4.

Rao, K.S., Anand, S., Venkateswarlu, P. 2011. Adsorption of cadmium from aqueous solution by Ficus religiosa leaf powder and characterization of loaded biosorbent. Acta Hydrochimica et Hydrobiologica, 39: 384-391.

Reddy, D.H.K., Harinath, Y., Seshaiah, K., Reddy, A. 2010a. Biosorption of $\mathrm{Pb}$ (II) from aqueous solutions using chemically modified Moringa oleifera tree leaves. Chemical Engineering Journal, 162: 626634.

Reddy, D.H.K., Harinath, Y., Seshaiah, K., Reddy, A.V.R. 2010b. Biosorption of $\mathrm{Pb}$ (II) from aqueous solutions using chemically modified Moringa oleifera tree leaves. Chemical Engineering Journal, 162: 626-634.

Salman, S.M., Ali, A., Khan, B., Iqbal, M., Alamzeb, M. 2019. Thermodynamic and kinetic insights into plant-mediated detoxification of lead, cadmium, and chromium from aqueous solutions by chemically modified Salvia moorcroftiana leaves. Environmental Science and Pollection Research, 26: 1433914349.

Saltali, K., Sari, A., Aydin, M. 2007. Removal of ammonium ion from aqueous solution by natural Turkish (Yildizeli) zeolite for environmental quality. Journal of Hazardous Materials, 141: 258-263.

Sangi, M.R., Shahmoradi, A., Zolgharnein, J., Azimi, G.H., Ghorbandoost, M. 2008. Removal and recovery of heavy metals from aqueous solution using Ulmus carpinifolia and Fraxinus excelsior tree leaves. Journal of Hazardous Materials, 155: 513-522.

Sari, A., Tuzen, M. 2009. Kinetic and equilibrium studies of biosorption of $\mathrm{Pb}$ (II) and $\mathrm{Cd}$ (II) from aqueous solution by macrofungus (Amanita rubescens) biomass. Journal of Hazardous Materials, 164: 1004-1011.

Schneegurt, M.A., Jain, J.C., Menicucci, J.A., Jr, Brown, S.A., Kemner, K.M., Garofalo, D.F., Quallick, M.R., Neal, C.R., Kulpa, C.F., Jr. 2001. Biomass by-products for the remediation of wastewaters contaminated with toxic metals. Environmental Science and Technology, 35: 3786-3791.

Shohreh, A., Ilunga, K., Memory, T. 2016. Evaluation of heavy metal removal from wastewater in a modified packed bed biofilm reactor. PIOS One, 11: $\mathrm{e} 0155462$.

Singh, K., Singh, A., Hasan, S. 2006. Low cost biosorbent 'wheat bran' for the removal of cadmium from wastewater: kinetic and equilibrium studies. Bioresource Technology, 97: 994-1001.

Soliman, A.M., Elwy, H.M., Thiemann, T., Majedi, Y., Labata, F.T., Al-Rawashdeh, N.A.F. 2016. Removal of $\mathrm{Pb}$ (II) ions from aqueous solutions by sulphuric acid-treated palm tree leaves. Journal of The Taiwan Institute of Chemical Engineers, 58: 264-273.

Wang, G., Zhang, S., Yao, P., Chen, Y., Xu, X., Li, T., Gong, G.J.A.J.o.C. 2018. Removal of $\mathrm{Pb}(\mathrm{II})$ from aqueous solutions by Phytolacca americana L. biomass as a low cost biosorbent. Arabian Journal of Chemistry, 11: 99-110.

Wang, Y.H., Lin, S.H., Juang, R.S. 2003. Removal of heavy metal ions from aqueous solutions using various low-cost adsorbents. Journal of Hazardous Materials, 102: 291-302.

Wei, L., Zhang, L., Peng, J., Ning, L., Zhang, S., 
Guo, S. 2008. Tobacco stems as a low cost adsorbent for the removal of $\mathrm{Pb}$ (II) from wastewater: Equilibrium and kinetic studies. Industrial Crops and Products, 28: 294-302.

WHO, 1996. Guidelines for Drinking-Water Quality. Health Criteria and Other Supporting Information. $2^{\text {nd }}$ edition, World Health Organization, Switzerland. Yan, G., Viraraghavan, T. 2010. Mechanism of biosorp- tion of heavy metals by Mucor rouxii. Engineering in Life Sciences, 8: 363-371.

Yang, J., Volesky, B. 1999. Biosorption of uranium on Sargassum biomass. Water Research, 33: 33573363.

Yu, J., Tong, M., Sun, X., Li, B. 2007. Cystine-modified biomass for $\mathrm{Cd}$ (II) and $\mathrm{Pb}$ (II) biosorption. Journal of Hazardous Materials, 143: 277-284. 